\title{
Impact of Digital Banking in India: Trends \& Challenges
}

\author{
Dr. Rachna Kalsan
}

Abstract - For the growth of any country's economy various sectors play a very important role. In the Indian economic growth banking sector is the most important aspects. Banking sector become the backbone of Indian economy. Any changes regarding technology or other aspects directly impact the growth of the economy. With the change in technology various changes occur in banking sector. Now more of customers are educated. They don't want to stand in queue for various activities like: Make payments, Deposit Cheque, Open bank accounts, Deposit Cheque and many more. With the change in time now digital banking introduced and it proves a star for the banking sector. Today's era accept this digital banking concept very easily and in a short time period it become more demanded mode of transaction in the market. In this paper we analyse the concept of digital banking. How it effects the human life. The research is based on secondary data. The concept of digital banking in banking industry brings numerous opportunities. But with every benefits some risk also introduced. And this digital banking also come with some risk.

Key words: Financial Inclusion, Digital Finance, Financial Products, Financial Services, Innovative Financial

Technology.

\section{INTRODUCTION}

Now banks are part of human life. Now Indian govt. do efforts to make cashless economy. In this process digital banking play a important role. In the present era we found ourselves in a wonderland, where the milkman accepts wallet payment without a fuss, a men buys a geometry set worth rs 100 using a credit card and the vegetable vendor uses QR code based "scan and pay" utility. The new innovative digital technologies and fantastic thoughts have given birth to whole new business and social dimensions. Digital banking provides solutions to bankers for their short term and long term business and technological requirements.

Digital Banking is the new paradigm in India which offers multiple benefits to the banking sector. It helps in increasing the productivity and profitability of banking sectors. It is a technological Updation in the growing era. This is mainly introduced to improve 4C's namely: Cost, Convenience, Control and Customer satisfaction. The framework/ structure of digital banking is the result of the collaborated efforts of the group comprising IDRBT research team, bankers, IT professionals and consultancy experts. The term digital is refers to the storage of data in the form of digital signals. It can make the banking function easy. ATM (Automatic Teller Machine) is an electronic telecommunication device. It is the best example of digital banking system. Digital banking makes the transaction very simple \& easy. SMS banking is the example. Now every customer is free and do their as per their convenience. Digital banking is part of the broader context for the move to online banking, where banking services are delivered over the internet.

Defination's:

1. "Digital Banking- a new concept in the era of electronic banking, which aims to enrich standard online and mobile banking services by integrating digital technologies, for example strategic analytics tools, social media interactions, innovative payment solutions, mobile technology and a focus on user experience".

2. "Digital Banking is the application of technology to ensure seamless end to end (STP in the 'old' jargon) processing of banking transactions/ operations; initiated by the client, ensuring maximum utility to the client in terms of availability, usefulness and cost; to the bank in terms of reduced operating cost, zero errors and enhanced services".

\section{Evaluation Of Digital BANKING IN INDIA}

The traditional system of banking in India has been the branch banking. The (MICR) Magnetic Ink Character Recognition based cheque processing was introduced during the period 1986- 88. The late 80's marked the emergence of computerisation of bank's with the introduction of LPM's (Ledger Posting Machines). The new economic policy gave motivation to introduce digital banking process in India in 90's. The year of 1991- 92 proves a successful year because of its rapid growth in the market. The major turning point was private and foreign 
banks came to Indian banking sector due to this New Economic Policy. It has born a high competitive market. And due to this the trend of digitalization arises. Now every bank wants to use digital banking services, so that they can give better services to their customers.

The challenges for banks are now facilitate demands that connect vendors with money through channels determined by the customers. This is a dynamic shape which is the base of customer satisfaction. It can be maintained by customer relationship management (CRM) software. This is an important aspect in digital banking. It can directly communicate with the customers. And it can be base to connect both customers and bank management.

\section{REVIEW OF LITERATURE}

1. Arunangshu in his paper focus on digitalization on rural banking system in India. Digital banking system have enormous potential to change the landscape of financial inclusion. They found that with the features of low cost, ease of use of digital banking can accelerate the integration of unbanked economy to the maintenance.

2. Rajeshwari in his research paper found that digital banking increase the expectations of customers from banks. With the help of secondary data they analyse that digital banking become the milestone in Indian banking system. It enhance the growth and progress of Indian banking. It found that due to digital banking the operating cost of banks has been reduced rapidly. Lower operating cost means more profits for the banks. According to him digital banking has a power change the banking structure.

3. Aarti Sharma, in his research paper concluded that digital banking will proves a milestone in the Indian economy. The study is analytical in nature and based secondary data. According to him digital banking impact on Indian economy. With the change in the technology of banking system, the economy also faces the changes. It can provide better services to their customers. Due to their rapid growth it is acceptable in the market. Now by analysing the benefits of digital banking everyone in the market demanded this for the overall growth and success.

4. Kiran Jindal conducted a research and analyse that with the promotion of digital banking it is also necessary to enhance awareness and preference of cutomers for banking products. It basically emphasis on HDFC banking products. The paper is based on empirical study. They can use primary data for the study. With the use of questionnaire they collect the data they analyse that age factor is most effective factors which effects the digital banking system. The customers over the age of 35 doesn't accept the change and still they are dependent upon public sector banks other than privet sector banks. Customers are not much aware with the new technology. So it is very important for the success of digital banking is to promote awareness among customers. For analysing the data researcher use SPSS software.

5. Ruby in his paper studied the problems and prospects of E- Banking. It also focus on the pros and cons of digital banking which effects the customers perceptions. They also focus on the risk involved while introducing digitalisation in the market. The secondary data was used for the research paper. They concluded that E- Banking offered a high level of convenience for managing finance for the customer in the digital market. They also analysed the risk means financial security, personal privacy towards the customers

6. Vishal conducted a study and concluded that customers always want safety and security during cash transactions. This paper makes more emphasis on the perception and opinion of urban mobile banking users. He focuses on practices, challenges and security issues related mobile banking in India. He uses quota sampling method. The data is collected from the primary source of data. The sample size is 100 respondents divided into two catagories: 50 users and 50 non- users of mobile banking. The sample is taken from Ghaziabad city. It was analysed that knowledge regarding use of mobile phone was the most important issue in mobile banking due to availability of various handsets models supporting different types of technology in the market.

7. Chandrawati identify the drivers of digital banking transformation for Indian banking system. ETechnology has become a tool that facilitates banks' organizational structures, business strategies, customer services and related functions. Using exploratory research, the study concluded that digitalization changed the face of branch banking and mobile was being increasingly used as a primary channel of banking. Moreover, integration with social media components as their online channels was also a major driver for digital banking transformation

8. Sahu and Kumar studied the important factors responsible for successful implementation of digital payment (e-Payment) system in India. Conducting a qualitative study with extensive literature review and using interview and expert opinion, 13 success factors namely Anonymity, Bank Involvement, Drawer, Infrastructure, Mobility, Parties, Popularity, Range of Payment, Risk, Security, Transfer limit, Transfer mode, and Transfer time were responsible for successful implementation of digital payment at Allahabad city.

9. Ankit and Singh conducted a study to analyses the impact of technology acceptance model (TAM) in the context of internet banking adoption in India under security and privacy threat. Keeping the TAM proposed by Davis as a theoretical basis, the paper 
revealed that perceived risk had a negative impact on behavioural intention of internet banking adoption and trust had a negative impact on perceived risk. A well-designed web site was also found to be helpful in facilitating easier use and also minimizing perceived risk concerns regarding internet banking usage.

10. Geetha conducted a study on 200 respondents of metropolitan city in India. The researcher has laid down various parameters which has direct impact on the adoption of E- Banking facilities. They specified the parameters like innovativeness, familiarity, awareness, security and trust among the various customers. These factors effects the customers perception regarding digital banking.

11. Utpala conducted a study to evaluate the current status of E- Banking in the market. From the primary source of data she analyse the respondents reviews about Ebanking. It will cover the Indian respondents as well as the non- residence respondents of India. They analyse the hurdles faced by the customers during online banking. They found that $60 \%$ of the urban population using digital banking. So for banks it should be important to focus on rural population by creating awareness programmes and training session. It should help in promoting digital banking in India.

12. Hoehle note that the utilization of digital banking channels has grown substantially. It focus on the customer related issue. They analyzed that if banks can use this digital banking system it can improve the financial performance of banks. Customers are looking for value and demanding more mobile banking services.

\section{RESEARCH METHODOLOGY}

\section{Objectives of the Study:}

1. To know the role of Digital Banking among Adults life.

2. To identify the services provided by Indian banks to promote digital banking.

3. To know the Pros \& Cons of Digital Banking.

4. To understand the challenges of digital banking.

\section{Data Collection Methods:}

The data should be collected with a secondary source. Various research papers, bank data, banking structure should be analysed for this paper.

\section{Results}

Objective 1: To know the role of Digital Banking among Adults life.

Now the time has been changed. With the change in technology human life also changes. In the past people go to banks and do their works by their own. But now all are educated and adopts new technologies for their growth. Now no one is like to go to banks because of shortage of time. All are busy in their jobs. I'm sure any one of them not wants to stand in queue for depositing money or to withdrawal of money. Everyone wants comfort and peace in their life. In the past this system of queue is applied. Now smart banking starts. And this smart banking is come in our way of life. It is a part of our life. Now every transaction is done through mobile banking. Now paying bills with mobile banking become very easy.

\begin{tabular}{|l|l|}
\hline Years & No. Of Mobile Users in Millions \\
\hline 2013 & 524.9 \\
\hline 2014 & 581.1 \\
\hline 2015 & 638.4 \\
\hline 2016 & 684.1 \\
\hline 2017 & 730.7 \\
\hline 2018 & 775.5 \\
\hline 2019 & 813.2 \\
\hline
\end{tabular}

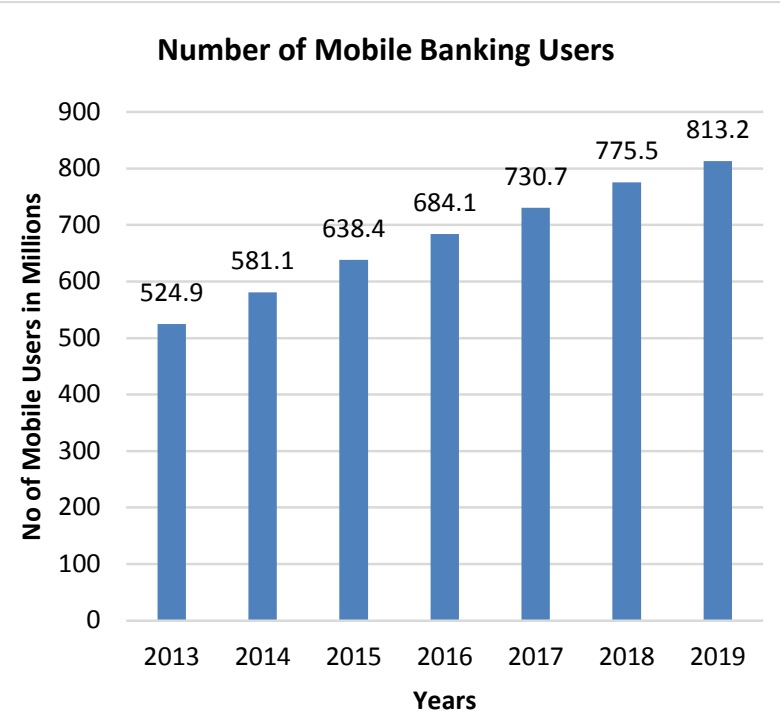

Number of adult Indians with bank accounts rises to $80 \%$

No. of Adults using Mobile Phone Banking

\begin{tabular}{|l|l|}
\hline Years & \% of people \\
\hline 2018 & $69 \%$ \\
\hline 2017 & $62 \%$ \\
\hline 2016 & $51 \%$ \\
\hline 2015 & $49 \%$ \\
\hline
\end{tabular}

Globally, 69\% of adults (3.8 billion adults) now using mobile banking. The Modi Government put more efforts to increase the use of digitalization in banking. India's JanDhan Yojana scheme, developed by the government to increase account ownership, brought an additional 310 million Indians into the formal banking system by March 2018, many of whom might not yet have had an opportunity to use their new account. 
In India the contribution of adults has been increased by doubled since 2011 with $80 \%$.

During 2017-18, the number of transactions carried out through credit cards and debit cards was 1.4 billion and 3.3 billion, respectively. Prepaid payment instruments (PPIs) recorded a volume of about 3.5 billion transactions, valued at Rs 1,416 billion. Indians prefer a digital-first approach to banking, and will not hesitate to protest poor service, finds a survey by Avaya. $\mathbf{5 1 \%}$ of Indians use online banking channels. $\mathbf{2 6 \%}$ of Indian customers prefer to access services via their bank's website, and the same number would prefer to use a mobile app rather than talk to a human agent.

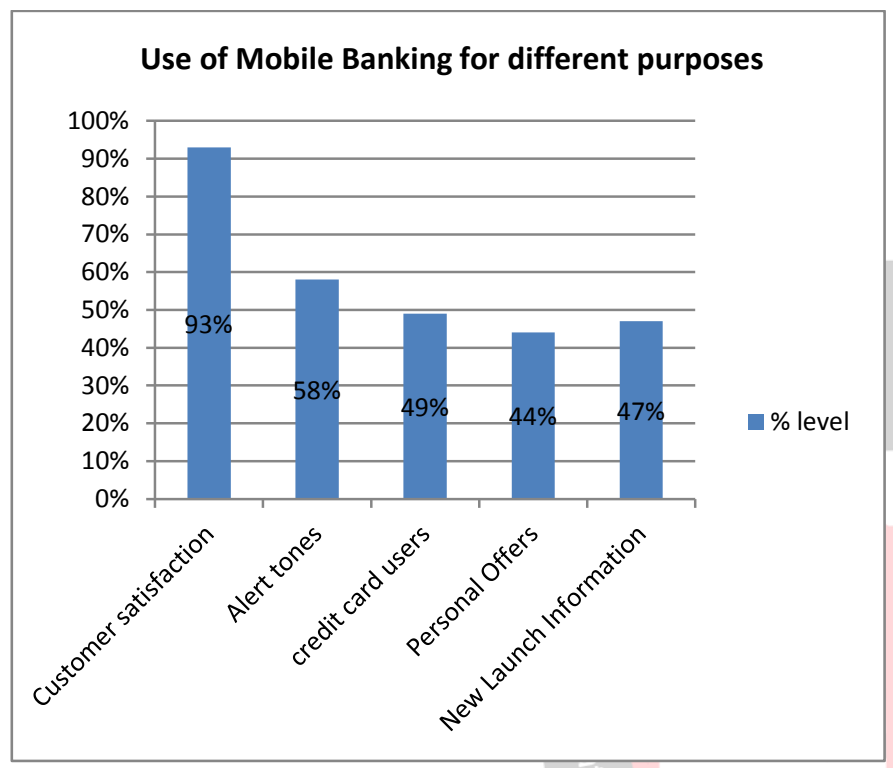

Benefits of Digital Banking for Student's:

1. No need to carry cash (plastic notes).

2. Avoid long queues.

3. Highly secured system.

4. No worry of loss and theft of money.

5. Easily availability of money.

6. One card- multiple uses.

7. Reduce operational expenses.

Digital banking Users according to Age Group:

\begin{tabular}{|l|l|}
\hline Age Group & \% of Users \\
\hline Below 18 & 33.3 \\
\hline $18-29$ & 78.6 \\
\hline $30-49$ & 67.5 \\
\hline $50-59$ & 33.3 \\
\hline 60 and Above & - \\
\hline
\end{tabular}

Objective 2: To identify the services provided by Indian banks to promote digital banking.

\begin{tabular}{|c|c|}
\hline S.no. & Services: \\
\hline 1 & Tablet banking. \\
\hline 2 & Mobile check denosit \\
\hline 3 & T. \\
\hline 4 & Tax alerts. \\
\hline 5 & E-Statements. \\
\hline 6 & \\
\hline
\end{tabular}

\begin{tabular}{|l|l|}
\hline 7 & Online Bill pay. \\
8 & Deposit Account opening. \\
9 & Account statement. \\
10 & Cheque book Issue. \\
11 & Fund Transfer facility. \\
& SMS Banking. \\
& Request status enquiry. \\
\hline
\end{tabular}

Objective 3: To know the Pros \& Cons of Digital Banking.

\begin{tabular}{|c|c|}
\hline $\begin{array}{l}\text { (Pros) Advantages of Digital } \\
\text { Banking: }\end{array}$ & $\begin{array}{l}\text { (Cons) Disadvantages of Digital } \\
\text { Banking: }\end{array}$ \\
\hline $\begin{array}{ll}\text { 1. } & \text { Customer Satisfaction. } \\
\text { 2. } & \text { Cost Reduction. } \\
\text { 3. } & \text { Paper less Work. } \\
\text { 4. } & \text { Face Competition. } \\
\text { 5. } & \text { Reduce Human Error. } \\
\text { 6. } & \text { Easy Accounts } \\
& \text { Handling. } \\
\text { 7. } & \text { Cash less Transactions. } \\
\text { 8. } & \text { Increased Productivity. } \\
\text { 9. } & \text { Increased employees } \\
& \text { Performance. } \\
\text { 10. } & \text { Time Saving. } \\
\text { 11. } & \text { Eliminate area gap. }\end{array}$ & $\begin{array}{l}\text { 1. Increase Cyber attacks. } \\
\text { 2. Afraid of Privacy \& } \\
\text { Security. } \\
\text { 3. Increased in } \\
\text { unemployment. } \\
\text { 4. Increase training and } \\
\text { development cost. } \\
\text { 5. It is not useful for } \\
\text { uneducated Peoples. } \\
\text { 6. Digital knowledge is } \\
\text { must. } \\
\text { 7. Customer's perception } \\
\text { changed. } \\
\text { 9. Low internet speed. } \\
\text { 10. Habitual causes. }\end{array}$ \\
\hline
\end{tabular}

Objective 4: To understand the challenges of digital banking.

1. Security/ Privacy: This is the most important challenge in digital banking. Every person has a doubt regarding privacy and security of digital banking. They don't believe on digitalisation. They only prefer to do cash transactions. Most of the customers were not changed their perception regarding banking. They think that with the growth of technology some problems also occur. Customers don't want to take any chance with their money which they have earn in their life with full of efforts and hard work. With digitalisation, antivirus also come which destroy your life.

2. Knowledge of Digitalisation: Many people don't understand the concept of digitalisation. This system wants Updation time to time to improve its accuracy. This digitalisation work only when the customers are educated and have knowledge regarding this. This is the challenge that it wants to cover more \& more customers. For this knowledge is most important.

3. Internal Barriers: Banking industry also has departments like other industry. With the change in technology effects the departments of the organisation. Like customers \& bank employees are the most important part of banking system. As customer knowledge regarding digital transaction is important as such employee's knowledge regarding digitalisation is also matters. If employees don't know this then how 
they can influence the customers. So banking system can give training to their employees so that they can update themselves with the change in technology. It can increase the performance \& productivity of employees.

4. Non financial Institutions: Like Govt. banks, several other institutions like Google, face book, paytm etc. offers similar services like banks provided to their customers. These non financial institutions provide a platform to the customers to send their money directly to someone's bank account. These institutions were not bounded with any rules and regulations. But financial institutions were bounded with some rules. This is the most challenging concept for financial institutions.

5. Digital banking system: Now a days the demand for digitalisation grow on a high speed. But most of the banks have no gutts to adopt this technique quickly. For this best and skilled management will be required so that their policies \& strategies will give benefits to the organisation. Some wants a readymade system and some wants to build a system and then implement it. It takes a lot of time to take a decision which is beneficial for the organisation. This makes a challenge for the organisation to adopt which system because each decision has with some cools $\&$ fires.

\section{Conclusion}

Digital banking captures a large market share. Now a days with technical advancement there is a change in the banking sector. Now every customer accept the digital banking for their comfort. But with benefits of this advancement some errors also occurs. So there are some technical issues which effects customers perception. According to the study the active users of digital banking are 562 millions in India. Digital banking is converting the brick and mortar banks into more greater and efficient places to operate. Digital banking makes easier all the transaction for the customers. They can easily pay their bills, convenient places, transfer money from one place to another and easily check the bank details. Growth of digital banking in India can help in various issues like: Growth of capital market, Growth of insurance sector, Growth of venture capital market.

\section{BIBLIOGRAPHY}

[1] Sharma Aarti, "Digital Banking in India: A Review of Trends, Opportunities and Challenges", IRJMST, vol. 8, issue 1, PP. 1680180.

[2] Aladwani A.M, "Online Banking: A Field study of drivers, development, challenges and expectations", International Journal of Information Management, vol. 21, pp. 213- 225.

[3] Rajeshwari M, "Digital Banking and Indian Perspective", International Journal of Economics and Finance, Vol. 10, issue 3, pp. 1- 5.
[4] Jindal Kiran, "Customer Awareness and Preference for Digital Banking offered by HDFC Bank: An Empirical Study", Journal of Internet Banking and Commerce.

[5] Avasthi G.P., "Information Technologi in Banking: Challengers for regulators", Prajnan International Journal, vol. 4, pp. 3- 17.

[6] Milind S, "Adoption of Internet Banking by Australian Consumers: An Empirical Investigation", International Journal of Bank Marketing, vol. 17, pp. 324- 334.

[7] Ruby S, "E- Banking: Problems and Prospects", International Journal of Management and Business studies, vol. 1.

[8] Vishal G, "Mobile Banking in India: Practices, Challenges and Security Issues", International Journal of Advanced Trends in Computer Science and Engineering, vol. 1, pp. 56- 66.

[9] Vanmali Utpala, "Digital Banking- Roadway to Success", International Journal of Marketing \& Financial Management, vol. 4, issue 8, pp. 39- 47.

[10] http://www.intel.in/content/dam/doc/financialservicesthe impact of mobile banking.pdf.

[11]Herzberg, "Payments and Banking with Mobile Personal Devices", Communication of ACM, vol. 46, issue 5.

[12] Sardana Varda, "Digital technology in the realm of Banking: A Review of Literature", International Journal of Research in Finance and Management, vol. 1 , issue 2, pp. 28- 32.

[13] Shah M, "E-Banking Management: Issues, Solution and Strategies", Information Science Reference Publication, New York.

[14] Chandrawati N, "Role of E- Banking Services Towards Digital India", International Journal of Commerce and Management Research, vol. 3, pp. 67- 71.

[15] Williamson, D.G, "Enhanced Authenication in Online Banking”, Journal of Economics Crime Management, vol. 4, issue 2, pp. 1- 25.

[16] Golden Anthony, "An Overview of Digitization in Indian Banking Sector”, Indo- Iranian Journal of Scientific Research, vol. 1, issue 1, pp. 209- 212.

[17]Golden and Regi, "Customer Preference towards Innovative Banking Practices available in the state bank of India at Palayamkottai", Sankhya international journal of management and technology, vol. 3 issue 11, pp. $1-5$.

[18] http://www.forbesindia.com/article/digital-revoluationin-the-indian-banking-sector/47811/1.

[19] Franco C, "Study on Impact of information technology in modern banking sector", Golden research thoughts, vol. 3, issue 11, pp.1-4.

[20] Koti K, “Customer Awareness and Adaptability towards Inter Banking: A Study of Indian Banking Industry", Social Research Journal, vol. 2, issue 8, pp. 63- 67. 